\title{
Environmental aspects of petroleum storage in above ground tank
}

\author{
Amgad Fathey Fayek Tadros* \\ Petroleum Pipelines Company, Mostorod, PO Box 1104, Cairo, Egypt
}

\begin{abstract}
Oil pollution is a severing global environmental problem causing a number of adverse negative impacts on human health air ecosystem and eventually the natural income that is why soil, water, air pollution with petroleum hydrocarbons have become the focus of increasing public and research concern petroleum hydrocarbon contaminants in the air environment are caused by human activities when harmful or excessive quantities of substances are introduced into Earth's atmosphere. Sources of air pollution include gases such as carbon monoxide, sulfur dioxide, hydrogen sulfide, methane, the aliphatic and polycyclic aromatic hydrocarbons (PAH's) fractions of petroleum are readily evolved to air during refinery and choosing the wrong storage tanks also leak to the soil change the chemical composition of spilled toxicity and biological impacts of the oil and add great difficulties to the identification of the residual spilled oil in the impacted environment and economic cost of air pollution in illness, health care costs, lost productivity so coordination between humans to conserves natural resources for future generation.
\end{abstract}

\section{Introduction}

Nowadays, energy is recognized as one of the main factors to the formation and development of industrial communities. The importance of Oil and petroleum is highlighted as their basically role at human life. Egypt has major importance at this field due to great capacity of energy resources, especially oil and gas, and also special geopolitical position. On the other hand, during recent year's oil products has decreased because of growing population and increasing demand to oil products and decreasing of crude oil extraction at compare to export.

However, to achieve suitable levels of production, the use of improved technologies should be considered via introducing new facilities that treat the crude oil sulphur and nitrogen to be stored in tanks with minimal pollution to the surrounding environment, another way to save oil products and prevent the evaporation loss or leakage by construction of storage tanks according to standard codes and preferred to be stored in floating roof tanks.

Evaporation of hydrocarbons and their products from on the above ground storage tanks has been of special concern in the recent years. Emissions from storage tanks are responsible not only for a depletion of the product supply but also for contributions to atmospheric air pollution.

Storage tank of hydrocarbons are important evaporation source of volatile organic compounds (VOC) and nonorganic gases such as carbon monoxide and hydrogen sulphide, etc.

In the present investigation the methods of hydrocarbon evaporation calculation are studied and measurement of pollution. Subsequently hydrocarbon evaporation and air pollution are computed and measured from Project Consulting Group (PCG) faculty of engineering Cairo university. All necessary parameters which influence evaporation from storage tanks are measured and types of polluted gas evolved are measured. Estimation of the pollutions of oil products from storage tanks requires comprehensive information. the required data has been provided to Arabian oil pipelines company and provide oil products.

The aim of the site to collect, distribute and products are transported under pressure through a pipeline 20" length $84 \mathrm{~km}$ connected to Petroleum Pipeline Company which own a network of pipelines located throughout Arab Republic of Egypt, the Arabian oil pipelines company. The site are compromised of loading arm shed for charging (shipping), the oil trucker with different type of oil products like (gas oil and gasoline and kerosene) and two pumps shed. The pump shed a composed of main pumps and booster pumps are used to transportation via pipelines and storage tanks or vice versa to other oil firms using pipelines the other pump shed (B) composed of shipping pumps and two circulation pump and firefighting pump shed has diesel pumps and jockey pumps. There is measurement of chimneys of diesel pumps to monitor.

The level of $\mathrm{SO}_{\mathrm{x}}$ and $\mathrm{NO}_{\mathrm{x}}$ and reducing it as possible finally 12 tanks, including six fixed roof and four floating roof tanks and two double roof tanks. The tanks are contained fuel oil, Gasoline and Kerosene. Ten tanks are active and one of them is under overhaul.

The cylindrical tanks are with diameter of 44 meters

\footnotetext{
* Corresponding author: chem_amgad_ppc@hotmail.com
} 
and height of 14.64 meters. This software is designed to estimate evaporation from organic liquid storage tanks and need to specific information about tank (dimensions, construction conditions and color ...), type of liquid (chemical components and liquid temperature ...) and position of the tank (nearest city, temperature and ...) to present the evaporation from these tanks to the air.

Final reports are included monthly and annual emission for each petroleum product or combination of chemicals is stored in the tank. Evaporation rate is considered from three tanks with number one, five and six, respectively containing diesel gas oil, gasoline and kerosene. Then the observed results were used to estimate emission values from the other storage tanks.

According to software results, the estimation of annual evaporation from a gas oil tank is about 2.9 tons per year that the 2.1 tons evaporation is in operation conditions and 0.8 tons evaporation is in static conditions.

There are the other three gas oil storage tanks, so the total emission of fixed roof storage tanks containing gas oil is about 8.7 tons per year. Three storage tanks contain gasoline. Because of gasoline is very volatile and the evaporation rate is noteworthy, tanks with floating roof is used to minimize environmental pollution it's consider environmentally friendly with concern to code during construction to avoid the leakage to soil.

Annual evaporation rate of the tanks with floating roof is 33.3 ton per year. Four storage tanks were contained kerosene. These tanks have floating roof. Annual evaporation rate of the one reservoir is about 0.5 ton, so total annual evaporation of the tanks is 2 tons per year. The present estimations show annual evaporations of about 8.7, 33.3 and 2 tons of Gas oil, Gasoline and Kerosene from Arabian oil pipelines storage tanks respectively. Therefore, such evaporation can have adverse effect on the air quality of surrounding areas. In view of economical aspects such losses Implementation of simple energy savings and as color of tanks, inner condition of shell and type of primary and secondary seals can reduce evaporation Gas oil, Gasoline and Kerosene from $8.7,33.3 \& 2$ ton/yr to $6.9,9.1 \&$ $0.4 \mathrm{ton} / \mathrm{yr}$ respectively.

We also recommend continues monitoring of storage tanks for any probable losses and minimization of polluted gas to the surrounding environment. In the future, it is suggested using cone shaped roofs while selecting among various fixed roofs.

Also, it is more logic to make use of primary and secondary seals in floating type roofs. The corrosion of inner surface of storage tanks must be controlled at minimum possible to protect soil and water supply resources if the tanks are constructed beside river or sea. It is also recommended to use white color throughout the outer surface of storage tanks.

\section{Environmental management of petroleum storage tank systems}

The exploration and exploitation activities of petroleum industry often causes environmental degradation that have significant impact on quality of air water soil vegetation and on health unless adequate preventive measures are planned.

To protect the natural environment, specifically air and soil and the water resources, from adverse effects that may result as a consequence of operating storage tank systems. This includes avoiding the contamination and negative ecological impacts from potential leaks and spills, and/or fires and explosions resulting from the release of petroleum products and/or allied petroleum products.

To mitigate the potential financial impacts, particularly due to spills and leaks as a result of the regular operations of storage tank systems at this industry, facilities, Community, and other buildings. That operate storage tank systems (all of the above will be referred to in this directive as institutions) to ensure that petroleum storage tank systems are operated, maintained and monitored.

\section{Environmental impacts of petroleum storage in above ground tank}

Petroleum industry take several steps via drilling the oil will followed by storage in tank crude oil then refinery and storage the products from the refinery process are also major contaminators of surface and ground water by leaking through the soil. The deep wells for the disposal of waste material end up in aquifers and ground water. Some of the refineries also discharge untreated waste material into the water bodies such as lakes and rivers. This means of waste disposal into the rivers affects the quality of water and the water animals. The petroleum products that find their ways into the water bodies are also highly inflammable and may cause river fires like has been the case of Cuyahoga River. Petroleum refining activities may also contaminate the soil.

Soil contamination includes the hazardous waste, oil spills, sludge from the treatment process, and coke dust. Soil contamination reduces the fertility of the soil and introduces foreign particles which may affect the growth and quality of crops.

One of the environmental impacts that may arise out of the implementation and operation of the storage tanking is oil spill and evaporization of products polluted the area each activity involves in the operation of tank farm has a potential spill risk and evaporization of different types of gases causing pollution.

\subsection{Chemicals}

They are also a major source of criteria air pollutants: sludge, nitrogen oxides $\left(\mathrm{NO}_{\mathrm{x}}\right)$, carbon monoxide $(\mathrm{CO})$, hydrogen sulfide $\left(\mathrm{H}_{2} \mathrm{~S}\right)$, and sulfur dioxide $\left(\mathrm{SO}_{2}\right)$. Refineries also release hydrocarbons such as natural gas (methane) and other light volatile fuels and oils.

Storage tanks also release fewer toxic hydrocarbons such as natural gas (methane) and other light volatile fuels and oils. Petroleum facilities including refinery and storage of crude oil and different products after the refinery process is a major source of pollution in areas 
where they are established. The entire process are major sources of toxic air pollutants including BTEX compounds, carbon monoxide, particulate matters, and sulfur dioxide. Some of toxic chemicals released into the air are suspect cancer-causing agents and are also responsible for the development of reproductive problems, and respiratory complications. A large amount of carbon monoxide emissions traps the heat in the earth leading to climate change.

\subsection{Measurements}

Standards used in performing tests: Multi gas monitor IR; Particulate monitor testo. Some characteristics of the equipments used in the study are given in Table 1.
The results of Table 3 and Table 3 are applicable only for the environmental conditions during the measuring process:

- Temperature $25.3 \pm 2 \mathrm{C}$;

- Relative Humidity $24 \pm 3 \%$.

Calibration certificate. Description Gas analyzer $\mathrm{CO}_{2}$ :

- Range: $0-5 \%$;

- Manufacturer: GFG, Model: G460II;

- Accuracy: 2\%,

- Environmental condition: $20^{\circ} \mathrm{C}$.

Basis of test the instrument has been calibrated by using multi gas dilution system traceable to SI units, according to EPA method (EPA-454 / B-13-003) (see Tables 4 and 5).

Table 1. Measuring equipment.

\begin{tabular}{|c|c|c|c|c|}
\hline Nomenclature & $\mathbf{p} / \mathbf{n}$ & $\mathbf{s} / \mathbf{n}$ & Report No. & Test method \\
\hline Multi Gas monitor IR & $\begin{array}{c}\text { RAE PGM 54 } \\
\text { Gas alert micro } 5 \\
\text { Microtector G460II }\end{array}$ & $\begin{array}{c}080-900996 \\
311-020192 \\
14031683\end{array}$ & $\begin{array}{l}\text { ENV } 1903 \\
\text { ENV } 1902 \\
\text { ENV } 1900\end{array}$ & $\begin{array}{c}\text { MCL }- \text { Multi Gas -01 } \\
\text { Based on EPA 600/8-97-036 }\end{array}$ \\
\hline Particulate monitor testo & $\begin{array}{l}\text { IMR2800A } \\
\text { Testo 330-1 }\end{array}$ & $\begin{array}{c}\text { D3602D27 } \\
01256553 / 609\end{array}$ & $\begin{array}{c}163 / 43 / 2012 \\
\text { ENV } 1900\end{array}$ & $\begin{array}{c}\text { MCL - Gas Analyzer -01 } \\
\text { Based on EPA-emit } \\
\text { M20, epa-m7e-m1 }\end{array}$ \\
\hline
\end{tabular}

Table 2. Measurement of $\left(\mathrm{SO}_{2}, \mathrm{NO}_{2}, \mathrm{NO}, \mathrm{CO}, \mathrm{CO}_{2}\right.$, VOC, Ozone, $\left.\mathrm{O}_{2}\right)$ for loading arm shed for shipping the truckers.

\begin{tabular}{|c|c|c|c|c|c|}
\hline Location name & Variables & $\begin{array}{l}\text { Mean } \\
\text { value }\end{array}$ & $\begin{array}{c}\text { Expanded } \\
\text { uncertainty }\end{array}$ & $\begin{array}{c}\text { Limit as law no. (9) for year } 2009 \\
\text { indicates as amended for the year } 2011\end{array}$ & Evaluation \\
\hline \multirow{8}{*}{ Loading arm shed' } & $\mathrm{SO}_{2}(\mathrm{ppm})$ & 0.5 & \pm 0.1 & 2 & Accepted \\
\hline & $\mathrm{NO}_{2}(\mathrm{ppm})$ & 0.3 & \pm 0.1 & 3 & Accepted \\
\hline & NO (ppm) & 2.5 & \pm 0.3 & 25 & Accepted \\
\hline & $\mathrm{CO}(\mathrm{ppm})$ & 9.0 & \pm 0.8 & 25 & Accepted \\
\hline & $\mathrm{CO}_{2}(\mathrm{ppm})$ & 815 & \pm 8.0 & 5000 & Accepted \\
\hline & VOC (ppm) & 3.5 & \pm 0.2 & N.A & N.A \\
\hline & Ozone (ppm) & 15.0 & \pm 1.5 & 120 & Accepted \\
\hline & $\mathrm{O}_{2}(\%)$ & 21.2 & \pm 0.2 & $18 \%$ & Accepted \\
\hline \multirow{8}{*}{$\begin{array}{l}\text { Next to tank } \\
\text { Kersone } .02\end{array}$} & $\mathrm{SO}_{2}(\mathrm{ppm})$ & 0.4 & \pm 0.1 & 2 & Accepted \\
\hline & $\mathrm{NO}_{2}(\mathrm{ppm})$ & 0.4 & \pm 0.1 & 3 & Accepted \\
\hline & NO (ppm) & 1.9 & \pm 0.3 & 25 & N.A \\
\hline & $\mathrm{CO}(\mathrm{ppm})$ & 9.0 & \pm 0.7 & 25 & Accepted \\
\hline & $\mathrm{CO}_{2}(\mathrm{ppm})$ & 850 & \pm 9.0 & 5000 & N.A \\
\hline & VOC (ppm) & 2.8 & \pm 0.3 & N.A & N.A \\
\hline & Ozone (ppm) & 14.0 & \pm 1.2 & 120 & Accepted \\
\hline & $\mathrm{O}_{2}(\%)$ & 21.2 & \pm 0.2 & $18 \%$ & Accepted \\
\hline \multirow{7}{*}{$\begin{array}{c}\text { Next to the company fence } \\
\text { near the suez road }\end{array}$} & $\begin{array}{c}\mathrm{SO}_{2} \\
\text { (microgm } / \mathrm{m}^{3} \text { ) }\end{array}$ & 95.1 & \pm 10.2 & 350 & Accepted \\
\hline & $\begin{array}{c}\mathrm{NO}_{2} \\
\text { (microgm } / \mathrm{m}^{3} \text { ) }\end{array}$ & 76.2 & \pm 8.10 & 300 & Accepted \\
\hline & $\begin{array}{c}\mathrm{NO} \\
\left(\mathrm{microgm} / \mathrm{m}^{3}\right)\end{array}$ & 57.6 & \pm 8.4 & N.A & N.A \\
\hline & $\begin{array}{c}\mathrm{CO} \\
\left(\mathrm{microgm} / \mathrm{m}^{3}\right)\end{array}$ & 10.4 & \pm 0.8 & 30 & Accepted \\
\hline & $\begin{array}{c}\mathrm{CO}_{2} \\
\left(\text { microgm } / \mathrm{m}^{3}\right)\end{array}$ & 350 & \pm 7.0 & N.A & N.A \\
\hline & VOC (ppm) & 2.0 & \pm 0.1 & N.A & N.A \\
\hline & $\mathrm{O}_{2}(\%)$ & 21.2 & \pm 0.3 & $18 \%$ & Accepted \\
\hline
\end{tabular}

Multi gas monitor device conduct chemical analysis on sample streams to flow from the process equipment into an analyzer sometimes conditioning the sample stream in between such as reducing pressure or changing the sample temperature is widely used for atmospheric air analysis, including applications for healthcare and environmental monitoring moreover these devices enable high throughout real time monitoring. These tests 
are applied using devices such as (RAE) and (Gas alert micro 5) and (Microtector G460II) is the most advanced portable chemical detector With the flexibility of up to six gas sensors this multi-gas monitor is versatile and customizable, while delivering real-time access to instrument readings and alarm status from any location these device contains electrical pump that withdraw air sample that detect the presence of gases in area during the refinery or storage in petroleum tanks, it can detect combustible and toxic and flammable and oxygen depletion, these detectors technology are combustible gas sensor, photo ionization detector (PID), infrared sensors, electrochemical gas sensors the electrical pump withdraw air sample to be analyzed and it depend of the detection the detectors types the (PID) is a portable vapor and gas detector that detects a variety of organic compounds.

Table 3. Measured parameter: Air pollutants concentration from chimneys measurement $\left(\mathrm{SO}_{2}, \mathrm{NO}_{\mathrm{x}}, \mathrm{CO}\right)$.

\begin{tabular}{|c|c|c|c|c|c|}
\hline Location name & Variables & $\begin{array}{l}\text { Mean } \\
\text { value }\end{array}$ & \begin{tabular}{|c|} 
Expanded \\
uncertainty
\end{tabular} & $\begin{array}{c}\text { Limit as law no (9) for year } 2009 \text { indicates as amend } \\
\text { for the year } 2011\end{array}$ & Evaluation \\
\hline \multirow{3}{*}{ Generator } & $\begin{array}{c}\mathrm{CO} \\
\left(\mathrm{milli} \mathrm{gm} / \mathrm{m}^{3}\right)\end{array}$ & 120.3 & \pm 11.9 & 250 & Accepted \\
\hline & $\begin{array}{c}\mathrm{SO}_{\mathrm{x}} \\
\left(\mathrm{microgm} / \mathrm{m}^{3}\right) \\
\end{array}$ & 350.4 & \pm 24.1 & 1300 & Accepted \\
\hline & $\begin{array}{c}\mathrm{NO} \\
\left(\text { microgm } / \mathrm{m}^{3}\right) \\
\end{array}$ & 392.4 & \pm 31.4 & 500 & Accepted \\
\hline \multirow{3}{*}{$\begin{array}{l}\text { Firefighting diesel } \\
\text { pump }\end{array}$} & $\begin{array}{c}\mathrm{CO} \\
\left(\mathrm{milli} \mathrm{gm} / \mathrm{m}^{3}\right) \\
\end{array}$ & 158.3 & \pm 13.2 & 250 & Accepted \\
\hline & $\begin{array}{c}\mathrm{SO}_{\mathrm{x}} \\
\left(\mathrm{microgm} / \mathrm{m}^{3}\right) \\
\end{array}$ & 450.4 & \pm 26.8 & 1300 & Accepted \\
\hline & \begin{tabular}{c|c|}
$\mathrm{NO}_{\mathrm{x}}$ \\
$\left(\mathrm{microgm} / \mathrm{m}^{3}\right)$
\end{tabular} & 421.4 & \pm 29.4 & 500 & Accepted \\
\hline
\end{tabular}

Photo ionization occurs when an atom or molecule absorbs light of sufficient energy to cause an electron to leave and create a positive ion. The PID is comprised of an ultraviolet lamp that emits photons that are absorbed by the compound (bombardment of air sample) in an ionization chamber. Ions (atoms or molecules that have gained or lost electrons and thus have a net positive or negative charge) produced during this process are collected by electrodes.

The current generated provides a measure of the analyte concentration. Because only a small fraction of the analyte molecules are actually ionized, this method is considered nondestructive to measure volatile organic compounds and other gases in concentrations from sub parts per billion to 10000 parts per million the other type of sensor electrochemical used for detecting oxygen and toxic gases.

More specifically, they measure the concentration of a specific gas within an external circuit. This is done by method of oxidation or reduction reactions. These reactions generate the positive or negative current flow through said external circuit the third type Microtector G460II

Use IR sensor for $\left(\mathrm{O}_{2}, \mathrm{H}_{2} \mathrm{~S}, \mathrm{CO}, \mathrm{CO}_{2}\right.$ and combustible gases, in particular, $\mathrm{NO}_{2}, \mathrm{SO}_{2}$ and a variety of other gases) and combustible gases (LEL and 100\% vol.) for a non-toxic atmosphere.

Measures trace gases by determining the absorption of an emitted infrared light source through a certain air sample. The report expanded uncertainty values are based on a standard uncertainty multiplied by a coverage factor $(K=2)$, providing a level of confidence of approximately $95 \%$. The uncertainty evaluation has been carried out in accordance with (ukas) requirements.

The standards used to perform this test are traceable to standard defined and maintains and disseminated by the (NIS) or other international standards organization or have been derived from accepted values of natural physical constants.

The result shown in this report is applicable only for the environmental conditions during the test itself.

Table 4. Calibration result Gas analyzer $\mathrm{CO}_{2} \mathrm{G} 460 \mathrm{II}$.

\begin{tabular}{|c|c|c|}
\hline $\begin{array}{c}\text { Applied values } \mathrm{CO}_{2}, \\
\mathbf{\%}\end{array}$ & $\begin{array}{c}\text { Reading values } \mathrm{CO}_{2}, \\
\mathbf{\%}\end{array}$ & $\begin{array}{c}\text { Error } \mathrm{CO}_{2}, \\
\mathbf{\%}\end{array}$ \\
\hline 0 & 0 & 0 \\
\hline 0.5 & 0.51 & 0.01 \\
\hline 1 & 1.05 & 0.05 \\
\hline 2 & 2.3 & 0.3 \\
\hline 3 & 3.3 & 0.3 \\
\hline
\end{tabular}

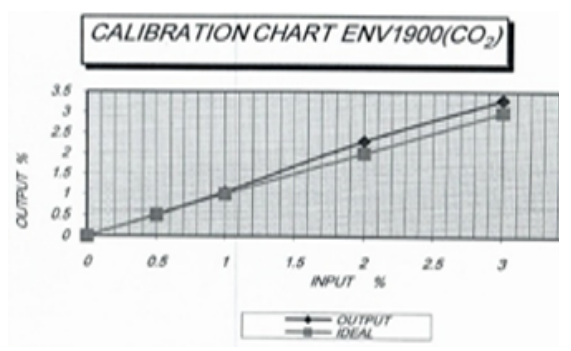

Fig. 1. Calibration chart of Gas analyzer $\mathrm{CO}_{2} \mathrm{G} 460 \mathrm{II}$.

The calculated uncertainty $= \pm 2.839 \%$.

The reported expanded uncertainty is based on a standard uncertainty multiplied by a coverage factor.

Description gas analyzer $\left(\mathrm{SO}_{2}\right)$ :

- Range 0-20 ppm;

- Manufacturer: CFG, Model G460II;

- Accuracy: 2\%;

- Temperature $20^{\circ} \mathrm{C}$; 
- Humidity: $62.9 \%$.

Basis of test: the instrument has been calibrated by using multi gas dilution system traceable to SI units and according to EPA method (EPA-454/B-13-003).

Table 5. Calibration result Gas analyzer $\mathrm{SO}_{2} \mathrm{G} 460 \mathrm{II}$

\begin{tabular}{|c|c|c|}
\hline $\begin{array}{c}\text { Applied values SO} \\
\text { (ppm) }\end{array}$ & $\begin{array}{c}\text { Reading values } \mathbf{S O}_{2} \\
\text { (ppm) }\end{array}$ & $\begin{array}{c}\text { Error SO } \\
\mathbf{p p m}\end{array}$ \\
\hline 0 & 0 & 0 \\
\hline 3 & 3 & 0 \\
\hline 5 & 5 & 0 \\
\hline 8 & 8.1 & 0.1 \\
\hline 10 & 10.1 & 0.1 \\
\hline
\end{tabular}

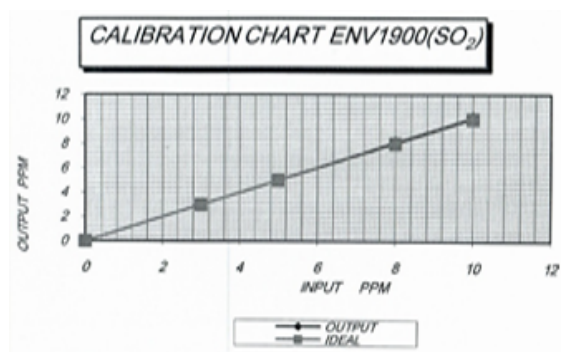

Fig. 2. Calibration chart of Gas analyzer $\mathrm{SO}_{2}$ G460II.

The calculated uncertainly $= \pm 2.83 \%$.

The reported expanded uncertainly is based on standard uncertainly multiplied by a coverage factor_ $\mathrm{K}=2$ providing a level of approximately $95 \%$.

From the results of previous measurements, it is clear that all the results of measurements comply with environmental law no. (9) of 2009 and the amendments for the year 2011.

\section{Results and discussion}

To decrease pollution potential, place tanks within a secondary containment structure consisting of a dike and a pad. All piping should be above ground within the dike or may go over the dike wall.

However, if it goes over the dike wall, it must be placed below the ground and within 10 feet of the dike wall. Above-ground piping must be made of steel and coated to prevent corrosion. Any below-ground piping may be either steel or fiberglass, but the steel piping must be coated and catholically protected, floating roof tank are preferred to prevent vaporization of gases which are responsible for pollution, spill protection usually consists of a catch basin for collecting spills when the tank is filled. Overfill protection is a warning device such as a buzzer or a prevention device such as an automatic shutoff. These precautions can prevent a number of small releases over time from polluting ground water.

Installation of flame arrestor and breathings valves to guarantee the safety of the tanks to avoid petroleum fires which lead the pollution to the environment with different kind of gases and toxic gases to control the air pollution and treatment of crude oil during the refinery process to eliminate the inorganic and organic contaminant especially sulfur to reduce the air pollution, monitoring the storage tanks with multi gas detector to evaluate the percentage of harmful gases and polluted gases to atmospheric air.

\section{References}

1. G.D. Hobson (ed.), Modern petroleum technology (Wiley, New York, 1973)

2. S.C. King, C. Reno, Piping Handbook (McGrawHill, 1973)

3. NFPA 30, Flammable and Combustible Liquids

4. NFPA 22, NFPA 32, For above ground storage tanks

5. M. Abdelmajeed, M.H. Onsa, A.A. Rabah, Evaluation and Reduction of Evaporation Losses of Gasoline Storage Tanks (Percon Engineering, University of Khartoum, 2008)

6. R.L. Ferry, J.R. Kissel, Manual of Petroleum Measurement Standards, chapter 19.1, 4th edn. (API, Washington, 2005)

7. September 2006. Emission Factor Documentation for AP-42 Section 7.1, Organic Liquid Storage Tanks. U.S Environmental Protection Agency, Office of Air Quality Planning and Standards, Emission Factor and Inventory Group, Research Triangle Park, NC 27711

8. Above-ground proprietary prefabricated oil storage tank systems. C535

9. Construction Industry Research and Information Association, Guide to sources of construction information, 4th edn. CIRIA Special Publication No. 30 (CIRIA, London, 1984)

10. E.L. Kemp, M.W. Caplinger, 19th century petroleum technology in North America (West Virginia University, Morgantown, 2007)

11. Special Waste Advisory Note 04 - Oil Contaminated Wastes. SEPA - on SEPA. 